\title{
Nutrient stock and nutritional efficiency of woody species in dry tropical forest as reforestation indicators ${ }^{1}$
}

\author{
Mozart Duarte Barbosa ${ }^{2}$,Fernando José Freire ${ }^{3 *}$ (D), Luiz Carlos Marangon ${ }^{4}$, Ana Lícia Patriota Feliciano ${ }^{4}$, \\ Rosival Barros de Andrade Lima 4 , Roseane Karla Soares da Silva
}

10.1590/0034-737X201966050008

\begin{abstract}
Efficient forest species can be indicated for reforesting environments, which present nutritional restriction. The objective of this study was to determine the nutrient stock in leaf biomass of the species of greatest importance value (IV) in a tropical dry forest fragment, as well as to evaluate the nutritional efficiency of these species as reforestation indicators. A phytosociological study of the woody species was carried out defining the ten species with the greatest IV. Three individuals of each species were selected and sampled, with 25 leaves being collected from the middle part of the crown of each individual. The $\mathrm{N}, \mathrm{P}, \mathrm{K}, \mathrm{Ca}$ and $\mathrm{Mg}$ contents were determined in these leaves and the leaf biomass was estimated by an allometric equation, calculating the stock of these nutrients and the nutritional efficiency of the species. The Schinopsis brasiliensis and Mimosa tenuiflora species can be recommended in environments with restricted P availability, and Spondias tuberosa can additionally be indicated to populate areas with low levels of K and $\mathrm{Mg}$ in the soil. Differences in the nutritional efficiency of the species can be attributed to the differences in the absorption and translocation capacity, as well as the utilization of these nutrients.
\end{abstract}

Keywords: biomass; caatinga; nutritional content; nutrient use.

\section{INTRODUCTION}

Plant species are directly related to the soil, seeking to find the necessary equilibrium for their establishment, which also interferes with species diversity (Silva et al., 2017). Thus, knowledge of the nutritional relations between plants and soil is fundamental, especially in environments with water restriction, as in dry tropical forests.

The nutritional efficiency of plant species expressed by leaf biomass production is determined by the relationship between this biomass and its nutrient stock. In forests, the biomass is all of the existing mass or only the tree fraction, also called forest phytomass or tree biomass (Sanquetta, 2002). Biomass can be quantified to study the stock and export of nutrients or to study nutrient balance and nutrient cycling (Alves et al., 2017).

Leaves are the organs which best reflect the nutritional status of plants (Malavolta, 2006). Thus, the nutritional efficiency of the species evaluated by the leaf biomass production is more adequate than an evaluation through the production of stems and branches, mainly for nutrient cycling studies (Albuquerque et al., 2018). According to Vitousek \& Sanford (1986), the mineral nutrient content in leaf tissues may reflect the soil's fertility, being useful to compare the nutritional condition of different areas. Medeiros et al. (2008) stated that only knowing the soil's fertility is insufficient for adequate monitoring of the nutritional state of plants.

\footnotetext{
Submitted on March 23 rd, 2019 and accepted on September 26 $6^{\text {th }}, 2019$.

${ }^{1}$ This work is part of first author's doctoral thesis with financial supporting of the CAPES and CNPQ.

${ }^{2}$ Autarquia de Ensino Superior de Arcoverde, Departamento de Biologia, Arcoverde, Brazil. barbosamd@ig.com.br

${ }^{3}$ Universidade Federal Rural de Pernambuco, Departamento de Agronomia, Recife, Brazil. fernando.freire@ufrpe.br

${ }^{4}$ Universidade Federal Rural de Pernambuco, Departamento de Ciência Florestal, Recife, Brazil. luiz.marangom@ufrpe.br; ana.feliciano@ufrpe.br; rosival barros@yahoo.com.br; roseanekarla.floresta@gmail.com

* Corresponding author: fernando.freire@ufrpe.br
} 
Nutritional efficiency expresses the plants' ability to absorb and utilize nutrients, being efficient when it produces more biomass per absorbed nutrient (Caldeira et al., 2004). This biomass production varies with the type of soil, species and environmental factors (Fontes et al., 2013). In fact, knowledge of nutritional aspects becomes an important tool to understand the establishment of plants in different soil types (Silva et al., 2017).

According to Batista et al. (2015), knowing the adaptability of a species under low soil fertility conditions can provide subsidies for the forest sector, helping the forestry worker when choosing the material to be used in the reforestation, as a lack of knowledge on the nutritional requirements of the species can compromise the success of native area recomposition projects (Carlos et al., 2013).

According to Lima et al. (2018b) when studied the nutritional efficiency of plants as an indicator of forest species for the restoration of forests in Brazil concluded that the nutritional utilization efficiency may indicate a diversified, established, and nutritionally balanced forest fragment, especially when there is a diversified contribution of the species to the nutrient cycling. Therefore, this study is of great importance, being concise but essential for the advancement of knowledge in the nutritional relations of species in dry forests.

Based on these aspects, this study aimed to determine the nutrient stock in leaf biomass of species with the greatest importance values (IV) in a tropical dry forest fragment, as well as to evaluate the nutritional efficiency of these species as reforestation indicators.

\section{MATERIAL AND METHODS}

\section{Characterization of the study area}

The dry tropical forest fragment studied belongs to the Caatinga Biome and is located on the Cavalcanti farm,
Ipojuca district in the municipality of Arcoverde/PE (Figure 1). The geographic coordinates of the fragment are: $8^{\circ} 01^{\prime} 03.6^{\prime \prime}$ South and 34'56'44.1" West, located in Mestoregião Sertão and in the Microregion Sertão do Moxotó in Pernambuco (Martins \& Cavararo, 2012).

In 1949, the northwest side of the fragment suffered deforestation for planting corn, beans and forage palm, and in 1954, the southeast side was used for tomato planting. Starting from 1960, all these areas were preserved under natural regeneration and grazed by goats and cattle.

The region presents BSh climate type according to the Köppen classification (Alvares et al., 2013), with an average annual temperature of $18.5^{\circ} \mathrm{C}$ and mean annual precipitation of $1100 \mathrm{~mm}$ (Martins \& Cavararo, 2012).

The soil of the fragment is classified as Ultisol (Santos et al., 2013). Soil sampling was carried out by collecting three simple samples in each of the 40 plots $\left(10^{\prime} 25 \mathrm{~m}\right)$ distributed in the fragment to form a composite, being performed in two depths $(0.0-0.10$; 0.10 $0.20 \mathrm{~m}$ ) (Table 1).

\section{Leaf nutrient sampling and analysis}

Leaf sampling was performed in the ten major IV species. These species were determined through previous studies of phytosociology, performed according to MüllerDombois \& Ellenberg (1974). The phytosociological structure of the tree-shrub component was determined in 40 sample units of $10 \mathrm{~m}$ x $25 \mathrm{~m}\left(250 \mathrm{~m}^{2}\right)$. All tree-shrub individuals with circumference at breast height $(\mathrm{CBH}>10$ $\mathrm{cm}$, at $1.30 \mathrm{~m}$ from the soil) were measured.

In the higher IV species, fresh leaves were randomly collected at the four cardinal points of each individual, and approximately 25 leaves were removed. Three individuals of each species were sampled, having the size similarity and the vegetative development of the

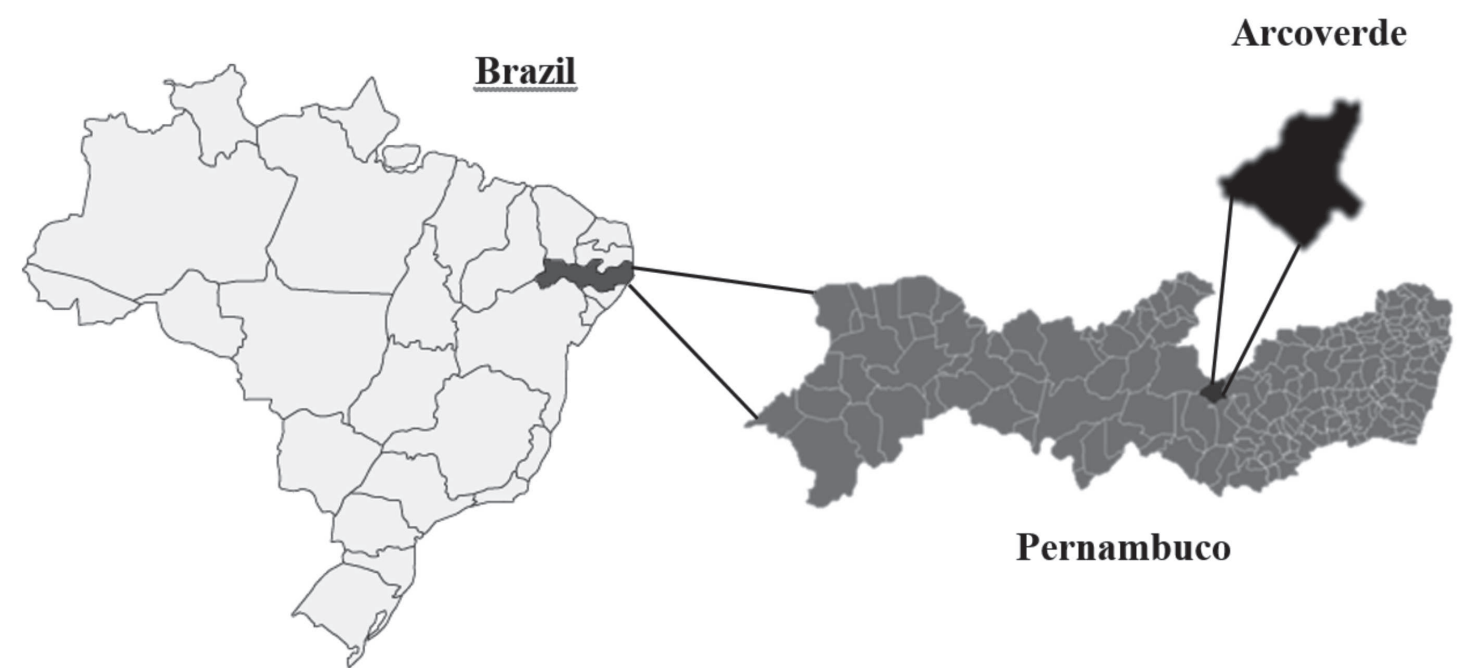

Figure 1: Location of the fragment in the municipality of Arcoverde, Pernambuco, Brazil.

Rev. Ceres, Viçosa, v. 66, n.5, p. 387-394, sep/oct, 2019 
individuals sampled as repetition selection criterion. The collected leaves were conditioned in paper bags and put in a forced air circulation oven at a temperature of $65^{\circ} \mathrm{C}$ until reaching constant weight, and then later crushed and stored for the chemical analyzes.

The $\mathrm{Ca}, \mathrm{Mg}, \mathrm{P}$ and $\mathrm{K}$ nutrients were extracted by nitroperchloric digestion. Then $\mathrm{Ca}$ and $\mathrm{Mg}$ were determined by atomic absorption spectrophotometry, $\mathrm{P}$ was dosed by colorimetry, and $\mathrm{K}$ determined by flame photometry (Silva, 2009). Also, N was extracted by sulfur digestion and determined by distillation and titration by the Kjeldahl method (Tedesco et al., 1995).

\section{Leaf biomass of forest species}

The leaf biomasses of the ten species with higher IV were estimated through allometric equations, which establish a relationship between the mean diameter-atbreast height (DBH) and leaf biomass, according to Silva $\&$ Sampaio (2008). These equations were adjusted to

Table 1: Chemical characterization and soil particle size distribution

\begin{tabular}{|c|c|c|}
\hline \multirow{2}{*}{ Attribute } & \multicolumn{2}{|c|}{ Depth (m) } \\
\hline & $0.0-0.10$ & $0.10-0.20$ \\
\hline $\mathrm{pH}\left(\mathrm{H}_{2} \mathrm{O}\right)$ & 5.43 & 5.43 \\
\hline $\mathrm{Ca}^{2+}\left(\mathrm{cmol}_{\mathrm{c}} \mathrm{dm}^{-3}\right)$ & 4.55 & 2.88 \\
\hline $\mathrm{Mg}^{2+}\left(\mathrm{cmol}_{\mathrm{c}} \mathrm{dm}^{-3}\right)$ & 2.78 & 4.60 \\
\hline $\mathrm{K}^{+}\left(\mathrm{cmol}_{\mathrm{c}} \mathrm{dm}^{-3}\right)$ & 0.47 & 0.39 \\
\hline $\mathrm{Al}^{3+}\left(\mathrm{cmol}_{\mathrm{c}}^{\mathrm{c}} \mathrm{dm}^{-3}\right)$ & 0.10 & 0.08 \\
\hline $\mathrm{H}+\mathrm{Al}\left(\mathrm{cmol}_{\mathrm{c}} \mathrm{dm}^{3}\right)$ & 6.81 & 5.86 \\
\hline $\mathrm{P}\left(\mathrm{mg} \mathrm{dm}^{-3}\right)^{\mathrm{c}}$ & 22.19 & 10.89 \\
\hline $\mathrm{Fe}\left(\mathrm{mg} \mathrm{kg}^{-1}\right)$ & 85.29 & 80.81 \\
\hline $\mathrm{Cu}\left(\mathrm{mg} \mathrm{kg}^{-1}\right)$ & 1.85 & 1.5 \\
\hline $\mathrm{Zn}\left(\mathrm{mg} \mathrm{kg}^{-1}\right)$ & 5.64 & 4.39 \\
\hline $\operatorname{Mn}\left(\mathrm{mg} \mathrm{kg}^{-1}\right)$ & 5.11 & 4.57 \\
\hline $\mathrm{SB}\left(\mathrm{cmol}_{\mathrm{c}} \mathrm{dm}^{-3}\right)^{(1)}$ & 7.80 & 7.87 \\
\hline CEC potential $\left(\mathrm{cmol}_{\mathrm{c}} \mathrm{dm}^{-3}\right)^{(2)}$ & 14.61 & 13.70 \\
\hline CEC effective $\left(\mathrm{cmol}_{\mathrm{c}} \mathrm{dm}^{-3}\right)^{(3)}$ & 7.90 & 7.95 \\
\hline $\mathrm{V}(\%)^{(4)}$ & 53.30 & 57.40 \\
\hline $\mathrm{m}(\%)^{(5)}$ & 1.30 & 1.00 \\
\hline TOC $\left(\mathrm{g} \mathrm{kg}^{-1}\right)^{(6)}$ & 15.6 & 10.5 \\
\hline $\mathrm{CO}_{\mathrm{HAF}}\left(\mathrm{g} \mathrm{kg}^{-1}\right)^{(7)}$ & 2.3 & 1.2 \\
\hline $\mathrm{CO}_{\mathrm{FAF}}\left(\mathrm{g} \mathrm{kg}^{-1}\right)^{(8)}$ & 1.6 & 3.2 \\
\hline $\mathrm{CO}_{\mathrm{HF}}\left(\mathrm{g} \mathrm{kg}^{-1}\right)^{(9)}$ & 9.9 & 5.5 \\
\hline $\mathrm{HS}\left(\mathrm{g} \mathrm{kg}^{-1}\right)^{(10)}$ & 13.8 & 9.9 \\
\hline Sand $\left(\mathrm{g} \mathrm{kg}^{-1}\right)$ & 790 & 790 \\
\hline Silt $\left(\mathrm{g} \mathrm{kg}^{-1}\right)$ & 100 & 100 \\
\hline Clay $\left(\mathrm{g} \mathrm{kg}^{-1}\right)$ & 90 & 90 \\
\hline
\end{tabular}

(1) SB: Sum of bases; ${ }^{(2)}$ CEC potential: Cation exchange capacity potential; ${ }^{(3)} \mathrm{CEC}$ effective: Cation exchange capacity effective; (4) $\mathrm{V}$ : Base saturation; ${ }^{(5)} \mathrm{m}$ : Aluminum saturation; ${ }^{(6)}$ TOC: Total organic carbon; ${ }^{(7)} \mathrm{CO}_{\mathrm{HAF}}$ : Organic Carbon of humic acids fraction; ${ }^{(8)} \mathrm{CO}_{\mathrm{FAF}}$ : Organic Carbon of fulvic acids fraction; ${ }^{(9)} \mathrm{CO}_{\mathrm{HF}}$ : Organic Carbon of the humina fraction; ${ }^{(10)} \mathrm{HS}$ : Humic substances. All the analytical procedures were according to Teixeira et al. (2017). estimate the leaf biomass of plants in the same biome of this study.

The mean DBH by species was obtained by the sum of the DBHs of all individuals, divided by the number of individuals. The leaf biomass of each species per area $(\mathrm{kg}$ $\mathrm{ha}^{-1}$ ) was obtained by multiplying the biomass by the number of individuals. The total leaf biomass was estimated by summing the biomass of all species (Espig et al., 2008).

\section{Stock and nutritional efficiency of species}

Determining the nutrient stock in leaf biomass of each species in $\mathrm{kg} \mathrm{ha}^{-1}$ was obtained by multiplying the content $\left(\mathrm{g} \mathrm{kg}^{-1}\right)$ by biomass.

The nutritional efficiency of the ten largest IV species of the fragment was calculated by the ratio between the leaf biomass of the species and the nutrient stock accumulated in the biomass (Espig et al., 2008).

\section{Statistical Analyses}

The assumptions of normality and homoscedasticity (Levene's test) of the data of content, stock and nutritional efficiency of the species for N, P, K, Ca e Mg were met for analysis of variance (ANOVA), as well as the independence was guaranteed with the use of sample casualization (Zar, 2010). According to Ferreira et al. (2012) when the assumptions of normality of errors, homogeneities of variances and independence of the residues are verified, the ANOVA is appropriately applicable. Thus, an F-test was applied at the 5\% probability level. When significant, the means were grouped by the Scott-Knott test at 5\% probability. This test was chosen because it better group the differences between species, avoiding the excessive number of letters due to the high quantity of species studied. The data were analyzed using ASSISTAT 7.7 statistical software (Silva \& Azevedo, 2016).

\section{RESULTS AND DISCUSSION}

\section{Leaf biomass}

The leaf biomass of the largest tree species and shrubs in the fragment varied from 31.6 to $1448.7 \mathrm{~kg} \mathrm{ha}^{-1}$ (Table 2). The tree species that presented the largest biomass were Poincianella pyramidalis and Mimosa ophthalmocentra, followed by the shrub species Croton blanchetianus and Jatropha mollissima. The Piptadenia stipulacea species had the lowest leaf biomass among the ten evaluated species (Table 2).

The work by Silva \& Sampaio (2008) selected nine Caatinga species to establish the models and the allometric equations to determine the leaf biomass in plants of this environment from the DBH. Among these selected plants, three species are among the ten species with higher IV in 
this study, specifically the two Croton blanchetianus and Jatropha mollissima shrub species and the Poincianella pyramidalis tree species, in addition to two genera $\mathrm{Mi}$ mosa and Schinopsis.

In evaluating the leaf biomass of five species with higher IV in dry tropical forest in a regenerated and preserved area, Alves et al. (2017) estimated values of $1,800 \pm 1,100$ to $4,500 \pm 2,100 \mathrm{~kg} \mathrm{ha}^{-1}$, respectively. For the Mimosa ophthalmocentra species, the authors reported a leaf biomass of $600 \mathrm{~kg} \mathrm{ha}^{-1}$ in a preserved area, being lower than that observed in this study. This suggests that this fragment is in an advanced regeneration stage, even though it has been subjected to impacting anthropogenic actions.

Biomass in tropical forests may vary according to the degree of conservation, age, forest composition and various biotic and abiotic factors (Dickow et al., 2012; Vendrami et al., 2012; Scoriza \& Pinã-Rodrigues, 2014). In Caatinga areas, Sampaio \& Freitas (2008) stated that the total biomass in these areas is mainly due to the availability of water.

\section{Nutrient contents in leaves of forest species}

The $\mathrm{N}$ content ranged from 16.98 to $33.32 \mathrm{~g} \mathrm{~kg}^{-1}$ (Table 3 ), constituting similar values to those found by Ribeiro Filho et al. (2007) and Medeiros et al. (2008), which were 26.7 to $35.3 \mathrm{~g} \mathrm{~kg}^{-1}$ and 16.1 to $31.4 \mathrm{~g} \mathrm{~kg}^{-1}$, respectively. $\mathrm{N}$ is one of the nutrients required in greater quantity by plants and which most limits growth (Pinto et al., 2011), being used in the synthesis of cellular compounds such as chlorophyll (Malavolta, 2006).

The $\mathrm{N}$ contents in the leaves of the species were higher than the other nutrients and did not differ among the species. In fact, $60 \%$ of the species are Fabaceae (Table 2), which have the ability to fix atmospheric $\mathrm{N}_{2}$ through the biological fixation of N (BFN) (Malavolta, 2006).

Silva et al. (2018) reported that BFN in tree species is responsible for high levels of $\mathrm{N}$ in leaves. Moura et al. (2006a) affirmed that $\mathrm{N}$ was the element, which presented the highest levels in the leaf biomass of the Mimosa caesalpiniifolia legume in their studies with plants of the Fabaceae family in stands located in the forest area region in Pernambuco. In the Caatinga forest, Alves et al. (2017) also found the highest levels of $\mathrm{N}$ in the leaves of the plants in both preserved area and in regeneration. In studying BFN in native forest species of areas with different regeneration times of the Caatinga, Freitas et al. (2015) found higher levels of N in legumes of the Mimosa genus.

P content in leaf biomass varied from 4.71 to $10.58 \mathrm{~g}$ $\mathrm{kg}^{-1}$ and differed among species (Table 3). The species that presented the highest levels of $\mathrm{P}$ were: Croton blanchetianus, Jatropha mollissima and Piptadenia stipulacea. This suggests that anthropic actions, which limit the regeneration, growth and establishment of these species, can compromise the $\mathrm{P}$ cycling of this fragment.

These results were generally higher than the observed by Alves et al. (2017), who found P leaf levels ranging from 1.7 to $2.9 \mathrm{~g} \mathrm{~kg}^{-1}$ in the regeneration area and contents ranging from 1.3 to $2.9 \mathrm{~g} \mathrm{~kg}^{-1}$ in preserved area. The $\mathrm{P}$ levels of this study were also higher than those found by Moura et al. (2006a) in the leaf biomass of Mimosa caesalpiniifolia $\left(0.7 \mathrm{~g} \mathrm{~kg}^{-1}\right.$ of $\left.\mathrm{P}\right)$, as well as those found by Medeiros et al. (2008) in 10 Caatinga tree-shrub species, where the contents varied from 1.1 to $3.3 \mathrm{~g} \mathrm{~kg}^{-1}$ of $\mathrm{P}$. The fragment's soil is rich in available $\mathrm{P}$ (Table 1), mainly on the surface, facilitating $\mathrm{P}$ absorption and accumulation by the plants, thus explaining the higher levels of $\mathrm{P}$ in this study.

The $\mathrm{K}$ levels ranged from 10.79 to $26.45 \mathrm{~g} \mathrm{~kg}^{-1}$, with high species differentiation (Table 3 ). The species with the highest $\mathrm{K}$ contents were Croton blanchetianus and Jatropha mollissima, while the lowest levels were found in Spondias tuberosa and Mimosa tenuiflora. Only two species were responsible for the higher $\mathrm{K}$ absorption, making them fundamental for K cycling in this fragment.

Table 2: Estimation of leaf biomass of the species with the greatest importance value (IV), family and plant-growth habitats

\begin{tabular}{lccc}
\hline Species & Biomass $\left(\mathbf{k g ~ h a}^{-\mathbf{1}}\right)$ & Family & Habitats \\
\hline Mimosa ophthalmocentra Mart. ex Benth. & $1,252.0$ & Fabaceae & tree \\
Poincianella pyramidalis (Tul.) L.P. Queiroz & $1,448.7$ & Fabaceae & tree \\
Schinopsis brasiliensis Engl. & 142.1 & Anacardiaceae & tree \\
Senegalia bahiensis (Benth.) Seigler \& Ebinger & 67.5 & Fabaceae & tree \\
Senegalia paniculata (Willd.) Killip & 57.1 & Fabaceae & tree \\
Croton blanchetianus Baill. & 233.6 & Euphorbiaceae & shrub \\
Jatropha mollissima (Pohl) Baill. & 150.4 & Euphorbiaceae & shrub \\
Spondias tuberosa Arruda & 142.1 & Anacardiaceae & tree \\
Mimosa tenuiflora (Willd.) Poir. & 94.7 & Fabaceae & tree \\
Piptadenia stipulacea (Benth.) Ducke & 31.6 & Fabaceae & tree \\
\hline Total & $\mathbf{3 . 6 1 9 . 8}$ & &
\end{tabular}

Rev. Ceres, Viçosa, v. 66, n.5, p. 387-394, sep/oct, 2019 
The K levels in this study were higher than the found by Moura et al. (2006a), Medeiros et al. (2008) and Alves et al. (2017). The high levels of soil K (Table 1) may also explain the higher absorptions of this nutrient in this study.

Regarding the $\mathrm{Ca}$ contents, it was verified that there was no difference between the species. The average content was $19.70 \mathrm{~g} \mathrm{~kg}^{-1}$ of $\mathrm{Ca}$, ranging from 14.35 to $22.52 \mathrm{~g} \mathrm{~kg}^{-1}$ (Table 3), therefore being higher than that established by Malavolta (2006) $\left(5.0 \mathrm{~g} \mathrm{~kg}^{-1}\right)$. In this case, all species were efficient in Ca uptake as also occurred with $\mathrm{N}$, suggesting that the responsibility for $\mathrm{Ca}$ and $\mathrm{N}$ cycling is not only concentrated in a group of species, but in all species with higher IV in the fragment. Lima et al. (2018b) reported that when the site is of low natural fertility, species do not differ in their ability to absorb and utilize nutrients. In the case of this study, soil $\mathrm{Ca}$ contents are high (Table 1) and the species did not differentiate. The species studied by Lima et al. (2018b) were tropical humid, naturally from less fertile soils (Turner et al., 2018).

Working in the same biome (Caatinga), Moura et al. (2006a) and Medeiros et al. (2008) found Ca contents in the species that ranged from 6.6 to $9.5 \mathrm{~g} \mathrm{~kg}^{-1}$ and 10.0 to $30.6 \mathrm{~g} \mathrm{~kg}^{-1}$, respectively. In working in two Caatinga areas (preserved and in regeneration), Alves et al. (2017) reported leaf contents ranging from 8.3 to $16.9 \mathrm{~g} \mathrm{~kg}^{-1}$ and 8.0 to 17.8 $\mathrm{g} \mathrm{kg}^{-1}$, respectively.

The $\mathrm{Mg}$ and $\mathrm{Ca}$ leaf contents did not differ between species and varied from 1.61 to $5.88 \mathrm{~g} \mathrm{~kg}^{-1}$, with a mean of $4.04 \mathrm{~g} \mathrm{~kg}^{-1}$ (Table 3). The Mg contents of this study were similar to those found by Alves et al. (2017). According to Malavolta (2006), Mg is part of the photosynthetic complex, meaning that it is part of the chlorophyll structure, with the highest $\mathrm{Mg}$ contents commonly being observed in the leaves.
The nutrient content in the biomass varies with the specificity of each nutrient due to the different levels of soil fertility, the nutritional demands of each species and the age of the forest (Helmisaari et al., 2002).

The two species that presented the highest levels of all the nutrients were from the Euphorbiaceae family: Croton blanchetianus and Jatropha molissima were the two species with the highest nutrient content, suggesting that this family may have some adaptive/nutritional characteristics, such as higher absorption capacity, providing higher nutrient contents in their leaves.

Alves et al. (2017) also found that Jatropha molíssima excelled in the absorption of these same nutrients, with the exception of Mg. Haridasan (2005) stated that higher nutrients levels in the plant may indicate greater nutrient availability in the soil, a higher nutritional requirement of the species, or better utilization of the nutrient by the species.

The differences in the contents and the diversity of species are fundamental, since they confer balance in the mineral nutrition, because species with greater accumulation capacity of a certain nutrient later make it available to the species with smaller capacity of absorption by way of cycling, thereby avoiding leaching losses and thus maintaining an integrated and stable system (Lima $e t$ al., 2018b).

\section{Nutrient stocks in leaf biomass}

$\mathrm{N}$ stocks in leaf biomass ranged from 0.96 to $34.75 \mathrm{~kg}$ $\mathrm{ha}^{-1}$, with a mean of $9.11 \mathrm{~kg} \mathrm{ha}^{-1}$ (Table 4). In working in the Caatinga regeneration area, Alves et al. (2017), found N stocks in the leaves of the species varying from 0.64 to $23.40 \mathrm{~kg} \mathrm{ha}^{-1}$, and ranging from 5.94 to $59.4 \mathrm{~kg} \mathrm{ha}^{-1}$ in a preserved area. The $\mathrm{N}$ stock of the regenerated areas found by the authors was lower than of this study, while the stock in the preserved area was higher, reflecting the

Table 3: Nutrient contents in the leaves of the species with greatest importance value (IV)

\begin{tabular}{lccccc}
\hline \multirow{2}{*}{ Species } & \multicolumn{1}{c}{$\mathbf{N}$} & $\mathbf{P}$ & $\mathbf{K}$ & $\mathbf{C a}$ & $\mathbf{M g}$ \\
\cline { 2 - 6 } & \multicolumn{5}{c}{$\mathbf{g ~ k g}^{-1}$} \\
M. ophthalmocentra & $27.44 \pm 0.96^{\mathrm{ns}}$ & $6.00 \pm 0.88 \mathrm{~b}$ & $14.77 \pm 0.62 \mathrm{c}$ & $15.65 \pm 2.71^{\mathrm{ns}}$ & $3.93 \pm 1.23^{\mathrm{ns}}$ \\
P. pyramidalis & $23.98 \pm 2.76$ & $6.39 \pm 0.54 \mathrm{~b}$ & $14.15 \pm 0.62 \mathrm{c}$ & $22.16 \pm 4.59$ & $1.61 \pm 0.41$ \\
S. brasiliensis & $19.88 \pm 0.96$ & $4.71 \pm 0.08 \mathrm{~b}$ & $14.49 \pm 1.36 \mathrm{c}$ & $16.59 \pm 2.85$ & $4.43 \pm 3.03$ \\
S. bahiensis & $29.58 \pm 4.93$ & $6.69 \pm 0.14 \mathrm{~b}$ & $17.34 \pm 0.81 \mathrm{~b}$ & $19.34 \pm 8.28$ & $4.55 \pm 1.76$ \\
S. paniculata & $33.32 \pm 1.12$ & $6.33 \pm 0.71 \mathrm{~b}$ & $17.44 \pm 1.18 \mathrm{~b}$ & $21.94 \pm 6.76$ & $3.27 \pm 1.01$ \\
C. blanchetianus & $25.29 \pm 9.79$ & $10.58 \pm 0.50 \mathrm{a}$ & $26.45 \pm 1.39 \mathrm{a}$ & $22.52 \pm 4.92$ & $5.81 \pm 2.36$ \\
J. mollissima & $24.09 \pm 0.50$ & $10.27 \pm 3.81 \mathrm{a}$ & $25.85 \pm 2.49 \mathrm{a}$ & $22.34 \pm 4.89$ & $5.88 \pm 1.80$ \\
S. tuberosa & $21.37 \pm 0.70$ & $5.56 \pm 0.79 \mathrm{~b}$ & $10.79 \pm 2.55 \mathrm{~d}$ & $22.04 \pm 8.17$ & $2.37 \pm 0.71$ \\
M. tenuiflora & $16.98 \pm 8.41$ & $4.80 \pm 0.70 \mathrm{~b}$ & $12.58 \pm 0.54 \mathrm{~d}$ & $20.06 \pm 6.92$ & $4.93 \pm 2.92$ \\
P. stipulacea & $27.53 \pm 3.54$ & $8.46 \pm 0.15 \mathrm{a}$ & $19.82 \pm 1.28 \mathrm{~b}$ & $14.35 \pm 8.44$ & $3.71 \pm 1.49$ \\
\hline Mean & $\mathbf{2 4 . 9 4} \pm \mathbf{4 . 8 6}$ & $\mathbf{6 . 9 7} \pm \mathbf{1 . 3 6}$ & $\mathbf{1 7 . 3 6} \pm \mathbf{1 . 4 6}$ & $\mathbf{1 9 . 7 0} \pm \mathbf{6 . 3 1}$ & $\mathbf{4 . 0 4} \pm \mathbf{1 . 9 5}$ \\
\hline
\end{tabular}

Means followed by equal letters in the columns belong to the same group by the Scott-Knott test up to the 5\% probability level. ns Not significant. 
greater leaf biomass and the size of the individuals in the regenerated area. This is a finding that the hypoxerophilic Caatinga fragment of this study is in an advanced regeneration stage. Lodhiyal et al. (2002) stated that nutrient accumulation and distribution in different parts of the plant are influenced by the climate, species and age of the plant.

The species with the largest stocks of $\mathrm{N}$ were Poincianella pyramidalis and Mimosa ophthalmocentra (Table 4), both belonging to the Fabaceae family (Table 2). In the work carried out by Alves et al. (2017), species of this Family (Poincianella bracteosa and Mimosa ophthalmocentra) also presented higher N stocks.

The Poincianella pyramidalis and Mimosa ophthalmocentra species accumulated the most $\mathrm{N}$ in the fragment, because they presented high leaf biomass per area (1,448.7 and 1,252 $\mathrm{kg} \mathrm{ha}^{-1}$, respectively) (Table 2). The high leaf production of the Poincianella pyramidalis species was also responsible for the higher stocks of $\mathrm{P}$ (9.26 kg ha-1), K (20.51 kg ha-1) and Ca (32.11 kg ha' $\left.\mathrm{kf}^{-1}\right)$ of this species. In relation to $\mathrm{Mg}$, Mimosa ophthalmocentra presented higher stock (4.92 $\mathrm{kg} \mathrm{ha}^{-1}$ ) (Table 2). The high absorption capacity of a species may not reflect its importance in nutrient cycling if other variables such as biomass production are not considered. The Poincianella pyramidalis and Mimosa ophthalmocentra species did not excel in nutrient absorption (Table 3), but produced a large amount of leaf biomass (Table 2), making them the largest nutrient accumulator (Table 4).

The different nutrient stocks in the leaves may be related to the mobility of the elements within the plant (Caldeira et al., 2007). Alves et al. (2017) reported smaller nutrient stocks in Caatinga regeneration areas and higher in regenerated areas. This evidences the importance of preservation, because the more preserved the fragment, the greater the amount of biomass and the nutrient stock in the leaves, which will later be deposited in the soil.

\section{Nutritional efficiency of forest species}

Nutritional efficiency is the ability of species to convert nutrients, which are absorbed and accumulated in biomass (Espig et al., 2008). Forest species were more efficient in using one nutrient than another. For example, they more efficiently used $\mathrm{Mg}>\mathrm{P}>\mathrm{K}>\mathrm{Ca}>\mathrm{N}$. The usage efficiency of $\mathrm{P}, \mathrm{K}$ and $\mathrm{Mg}$ differed between species (Table 5). This variation in efficiency may be related to the nutrient's availability in the soil or may be an intrinsic characteristic of the species (Albuquerque et al., 2018).

$\mathrm{N}$ was the nutrient which was less efficiently used by the species (Table 5), but it was the most absorbed (Table 3 ) and stored in greater quantity in the plants (Table 4). The species did not differ in their $\mathrm{N}$ use (Table 5). In evaluating the nutrient utilization efficiency in Mimosa caesalpiniifolia, Moura et al. (2006b) observed that $\mathrm{N}$ was the nutrient used with lower efficiency. Alves et al. (2017) also observed lower N utilization by species, especially when they evaluated the nutrition of species in regenerated areas.

According to Caldeira et al. (2002), N is less efficiently utilized by the species when compared to other nutrients due to high leaf contents and internal retranslocation, returning to the soil through the litterfall and initiating nutrient cycling.

The species used $\mathrm{Mg}$ and $\mathrm{P}$ more efficiently, meaning that the species showed a high biomass conversion capacity even with low levels of these nutrients in the tissues. Carnevali et al. (2016) emphasized that this high efficiency is related to the role that these nutrients play in plant metabolism. According to Lima et al. (2018a), several reactions occur through dependence between these nutrients and begin with the role of $\mathrm{Mg}$ in the uptake of $\mathrm{P}$

Table 4: Nutrient Stock contents in biomass foliar of the species of greatest importance value (IV)

\begin{tabular}{lccccc}
\hline \multirow{2}{*}{ Species } & $\mathbf{N}$ & $\mathbf{P}$ & $\mathbf{K}$ & $\mathbf{C a}$ & $\mathbf{M g}$ \\
\cline { 2 - 6 } & \multicolumn{5}{c}{$\mathbf{k g ~ h a}^{-\mathbf{1}}$} \\
\hline M. ophthalmocentra & $34.36 \pm 1.21 \mathrm{a}$ & $7.51 \pm 1.10 \mathrm{~b}$ & $18.50 \pm 0.78 \mathrm{~b}$ & $19.60 \pm 3.40 \mathrm{~b}$ & $4.92 \pm 1.54 \mathrm{a}$ \\
P. pyramidalis & $34.75 \pm 4.00 \mathrm{a}$ & $9,26 \pm 0.79 \mathrm{a}$ & $20.51 \pm 0.90 \mathrm{a}$ & $32.11 \pm 6,65 \mathrm{a}$ & $2.34 \pm 0.60 \mathrm{~b}$ \\
S. brasiliensis & $2.83 \pm 0.13 \mathrm{~b}$ & $0.66 \pm 0.01 \mathrm{e}$ & $2.06 \pm 0.19 \mathrm{e}$ & $2.36 \pm 0.40 \mathrm{c}$ & $0.63 \pm 0.43 \mathrm{c}$ \\
S. bahiensis & $2.00 \pm 0.33 \mathrm{~b}$ & $0.45 \pm 0.01 \mathrm{e}$ & $1.17 \pm 0.05 \mathrm{f}$ & $1.31 \pm 0.56 \mathrm{c}$ & $0.30 \pm 0.11 \mathrm{c}$ \\
S. paniculata & $1.90 \pm 0.06 \mathrm{~b}$ & $0.36 \pm 0.04 \mathrm{e}$ & $1.00 \pm 0.06 \mathrm{f}$ & $1.25 \pm 0.38 \mathrm{c}$ & $0.18 \pm 0.06 \mathrm{c}$ \\
C. blanchetianus & $5.91 \pm 2.28 \mathrm{~b}$ & $2.47 \pm 0.11 \mathrm{c}$ & $6.18 \pm 0.32 \mathrm{c}$ & $5.26 \pm 1.14 \mathrm{c}$ & $1.35 \pm 0.54 \mathrm{~b}$ \\
J. mollissima & $3.70 \pm 0.01 \mathrm{~b}$ & $1.54 \pm 0.57 \mathrm{~d}$ & $3.89 \pm 0.37 \mathrm{~d}$ & $3.36 \pm 0.73 \mathrm{c}$ & $0.88 \pm 0.27 \mathrm{c}$ \\
S. tuberosa & $3.04 \pm 0.09 \mathrm{~b}$ & $0.79 \pm 0.11 \mathrm{e}$ & $1.53 \pm 0.36 \mathrm{e}$ & $3.13 \pm 1.16 \mathrm{c}$ & $0.34 \pm 0.10 \mathrm{c}$ \\
M. tenuiflora & $1.61 \pm 0.79 \mathrm{~b}$ & $0.45 \pm 0.07 \mathrm{e}$ & $1.19 \pm 0.05 \mathrm{f}$ & $1.90 \pm 0.65 \mathrm{c}$ & $0.46 \pm 0.27 \mathrm{c}$ \\
P. stipulacea & $0.96 \pm 0.11 \mathrm{~b}$ & $0.27 \pm 0.005 \mathrm{e}$ & $0.62 \pm 0.04 \mathrm{f}$ & $0.45 \pm 0.26 \mathrm{c}$ & $0.11 \pm 0.04 \mathrm{c}$ \\
\hline Mean & $\mathbf{9 . 1 1} \pm \mathbf{1 . 5 7}$ & $\mathbf{1 . 6 1} \pm \mathbf{0 . 3 1}$ & $\mathbf{5 . 6 7} \pm \mathbf{0 . 4 4}$ & $\mathbf{7 . 0 7} \pm \mathbf{2 . 4 6}$ & $\mathbf{1 . 1 5} \pm \mathbf{0 . 6 0}$ \\
\hline
\end{tabular}

Means followed by equal letters in the columns belong to the same group by the Scott-Knott test up to the $5 \%$ probability level.

Rev. Ceres, Viçosa, v. 66, n.5, p. 387-394, sep/oct, 2019 
Table 5: Nutritional efficiency of the species of greatest importance value (IV)

\begin{tabular}{lccccc}
\hline \multirow{2}{*}{ Species } & $\mathbf{N}$ & $\mathbf{P}$ & $\mathbf{K}$ & $\mathbf{C a}$ & $\mathbf{M g}$ \\
\cline { 2 - 6 } & \multicolumn{5}{c}{$\mathbf{k g ~ k g}^{-\mathbf{1}}$} \\
\hline M. ophthalmocentra & $36.47 \pm 1.26^{\mathrm{ns}}$ & $168.93 \pm 24.57 \mathrm{~b}$ & $67.77 \pm 2.84 \mathrm{~b}$ & $65.09 \pm 10.61^{\mathrm{ns}}$ & $274.18 \pm 95.90 \mathrm{~b}$ \\
P. pyramidalis & $42.04 \pm 4.55$ & $157.07 \pm 14.03 \mathrm{~b}$ & $70.73 \pm 3.09 \mathrm{~b}$ & $46.46 \pm 9.78$ & $643.84 \pm 146.88 \mathrm{a}$ \\
S. brasiliensis & $50.38 \pm 2.39$ & $211.94 \pm 3.66 \mathrm{a}$ & $69.41 \pm 6.76 \mathrm{~b}$ & $61.55 \pm 11.12$ & $306.79 \pm 190.09 \mathrm{~b}$ \\
S. bahiensis & $34.49 \pm 6.21$ & $149.49 \pm 3.25 \mathrm{~b}$ & $57.74 \pm 2.77 \mathrm{c}$ & $59.47 \pm 28.08$ & $251.50 \pm 124.16 \mathrm{~b}$ \\
S. paniculata & $30.03 \pm 1.01$ & $159.05 \pm 16.93 \mathrm{~b}$ & $57.50 \pm 4.07 \mathrm{c}$ & $48.76 \pm 15.80$ & $329.36 \pm 117.74 \mathrm{~b}$ \\
C. blanchetianus & $45.10 \pm 21.71$ & $94.65 \pm 4.42 \mathrm{c}$ & $37.86 \pm 1.98 \mathrm{~d}$ & $46.06 \pm 11.39$ & $190.00 \pm 66.86 \mathrm{~b}$ \\
J. mollissima & $40.54 \pm 0.06$ & $110.26 \pm 52.02 \mathrm{c}$ & $38.93 \pm 3.95 \mathrm{~d}$ & $46.22 \pm 10.17$ & $179.82 \pm 47.59 \mathrm{~b}$ \\
S. tuberosa & $46.82 \pm 1.53$ & $182.47 \pm 28.30 \mathrm{~b}$ & $96.78 \pm 26.49 \mathrm{a}$ & $50.79 \pm 22.28$ & $446.53 \pm 130.58 \mathrm{a}$ \\
M. tenuiflora & $76.31 \pm 52.86$ & $211.30 \pm 30.64 \mathrm{a}$ & $79.59 \pm 3.51 \mathrm{~b}$ & $54.48 \pm 20.49$ & $259.10 \pm 152.08 \mathrm{~b}$ \\
P. stipulacea & $36.75 \pm 5.05$ & $118.24 \pm 2.16 \mathrm{c}$ & $50.60 \pm 3.32 \mathrm{c}$ & $91.92 \pm 60.32$ & $305.89 \pm 139.62 \mathrm{~b}$ \\
\hline Mean & $\mathbf{4 3 . 8 9} \pm \mathbf{1 8 . 9 9}$ & $\mathbf{1 5 6 . 3 4} \pm \mathbf{2 4 . 6 5}$ & $\mathbf{6 2 . 6 9} \pm \mathbf{8 . 8 9}$ & $\mathbf{5 7 . 0 8} \pm \mathbf{2 5 . 2 4}$ & $\mathbf{3 1 8 . 7 0} \pm \mathbf{1 3 2 . 1 0}$ \\
\hline
\end{tabular}

Means followed by equal letters in the columns belong to the same group by the Scott-Knott test up to the 5\% probability level. ${ }^{\text {ns }}$ Not significant.

by plants, promoting their entry as companion ion. Martinoia et al. (2000) stated that the energy transfer reactions require $\mathrm{Mg}$ because most of the ATP present in the cell is complexed with $\mathrm{Mg}$.

The species that best used K were Spondias tuberosa, Mimosa tenuiflora and Poincianella pyramidalis (Table 5 ), which means that the use of these species may be adequate in environments where less $\mathrm{K}$ is available. Regarding the use of $\mathrm{Ca}$, the species Piptadenia stipulacea, Mimosa ophthalmocentra and Schinopsis brasiliensis were the most efficient (Table 5).

The Mimosa tenuiflora and Schinopsis brasiliensis species were able to establish themselves in environments with low $\mathrm{P}$ availability due to the high efficiency of these species in producing biomass using smaller quantities of P. Meanwhile, the Poincianella pyramidalis and Spondias tuberosa species can be introduced in environments with low availability of $\mathrm{Mg}$ because they present high efficiency of Mg use, while the Spondias tuberosa species can be recommended in areas with in K deficiency.

\section{CONCLUSIONS}

The species more efficiently utilized the nutrients in the following order: $\mathrm{Mg}>\mathrm{P}>\mathrm{K}>\mathrm{Ca}>\mathrm{N}$. The use of the Poincianella pyramidalis and Spondias tuberosa species can be recommended in reforestation projects in areas with low natural fertility, mainly for $\mathrm{Mg}$.

Additionally, the Schinopsis brasiliensis and Mimosa tenuiflora species can be recommended in environments with restricted availability of $\mathrm{P}$, and Spondias tuberosa can be indicated to populate areas with low $\mathrm{K}$ and $\mathrm{Mg}$ levels in the soil.

Differences in nutrient efficiency can be attributed to differences in the absorption, translocation, stocking and utilization capacity of these nutrients.

\section{CONFLICT OF INTERESTS}

The Authors declare that there is no conflict of interests in carrying the research and publishing the manuscript.

\section{REFERENCES}

Albuquerque AS, Freire FJ, Barbosa MD, Marangon LC \& Feliciano ALP (2018) Efficiency of biological utilization of micronutrients by forests species in hypoxerophytic Caatinga. Floresta e Ambiente, 25:e20170925.

Alvares CA, Stape JL, Sentelhas PC, Gonçalves JLM \& Sparovek G (2013) Köppen's climate classification map for Brazil. Meteorologische Zeitschrift, 22:711-728.

Alves AR, Ferreira RLC, Silva JAL, Dubeux Júnior JCB, Osajima JA \& Holanda AC (2017) Conteúdo de nutrientes na biomassa e eficiência nutricional em espécies da caatinga. Ciência Florestal, 27:377-390.

Batista RO, Neto AEF \& Deccetti SF (2015) Eficiência nutricional em clones de cedro-australiano. Scientia Forestalis, 43:647-655.

Caldeira MVW, Marques R, Soares RV \& Balbinot R (2007) Quantificação de serapilheira e de nutrientes-Floresta Ombrófila Mista Montana-Paraná. Revista Acadêmica, 5:101-116.

Caldeira MVW, Rondon Neto RM \& Schumacher MV (2002) Avaliação da eficiência nutricional de três procedências australianas de acácia-negra (Acacia mearnsii De Wild.). Revista Árvore, 26:615-620.

Caldeira MVW, Rondon Neto RM \& Schumacher MV (2004) Eficiência do uso de micronutrientes e sódio em três procedências de Acácia-negra (Acacia mearnsii De Wild.). Revista Árvore, 28:39-47.

Carlos L, Venturin N, Higashikawa EM, Santos SC \& Macedo RLG (2013) Crescimento e nutrição mineral de mudas de óleo-bálsamo sob o efeito da omissão de nutrientes. Enciclopédia Biosfera, 9:894-904.

Carnevali NHS, Marchetti ME, Vieira MC, Carnevali TO \& Ramos DD (2016) Eficiência nutricional de mudas de Stryphnidendron polyphyllum em função de nitrogênio e fósforo. Ciência Florestal, 26:449-461. 
Dickow KMC, Marques R, Pinto CB \& Hofer H (2012) Produção de serapilheira em diferentes fases sucessionais de uma floresta subtropical secundária, em Antonina, PR. Revista Cerne, 18:7586.

Espig SA, Freire FJ, Marangon LC, Ferreira RLC, Freire MBGS \& Espig DB (2008) Composição e eficiência da utilização biológica de nutrientes em fragmento de Mata Atlântica em Pernambuco. Ciência Florestal, 18:307-314.

Ferreira DF, Cargnelutti Filho A \& Lúcio AD (2012) Procedimentos estatísticos em planejamentos experimentais com restrições na casualização. Boletim Informativo da Sociedade Brasileira de Ciência do Solo, 37:16-19.

Fontes AG, Gama Rodrigues AC \& Gama Rodrigues EF (2013) Eficiência nutricional de espécies arbóreas em função da fertilização fosfatada. Pesquisa Florestal Brasileira, 33:09-18.

Freitas ADS, Sampaio EVSB, Santos CERS, Silva AF \& Souza RJC (2015) Fixação biológica de nitrogênio no Semiárido Brasileiro. Revista Brasileira de Geografia Física, 8:585-597.

Haridasan M (2005) Competição por nutrientes em espécies arbóreas do cerrado. In: Scariot A, Souza Silva JC \& Felfili JM (Eds.) Cerrado: ecologia, biodiversidade e conservação. Brasília, Ministério do Meio Ambiente. p.167-178.

Helmisaari H, Makkonnen K, Kellomäki S, Valtonen E \& Mälkönen E (2002) Below-and above-ground biomass, production, and nitrogen use in Scots pine stands in eastern Finland. Forest Ecology and Management, 165:317-326.

Lima E, Vitti GC, Santos LA \& Cicarone F (2018a) Cálcio e Magnésio. In: Fernandes MS, Souza SR \& Santos LA (Eds.) Nutrição mineral de plantas. Viçosa, Sociedade Brasileira de Ciência do Solo. p.465-490.

Lima RBA, Freire FJ, Marangon LC, Feliciano ALP, Silva RKS, Freire MBGS \& Freire CS (2018b) Nutritional efficiency of plants as an indicator of forest species for the restoration of forests, Brazil. Scientia Forestalis, 46:415-426.

Lodhiyal N, Lodhiyal LS \& Pangtey YPS (2002) Structure and function of shisham forests in central Himalaya, Índia: nutrient dynamics. Annals of Botany, 89:55-65.

Malavolta E (2006) Manual de nutrição mineral de plantas. São Paulo, Editora Agronômica Ceres. 638p.

Martinoia E, Massonneau A \& Frangne N (2000) Transport processes of solutes across the vacuolar membrane of higher plants. Plant and Cell Physiology, 41:1175-1186.

Martins L \& Cavararo R (2012) Manual Técnico da Vegetação Brasileira. Rio de Janeiro, IBGE. 275p.

Medeiros MLD, Santos RV \& Tertuliano SSX (2008) Avaliação do estado nutricional de dez espécies arbóreas ocorrentes no semiárido paraibano. Revista Caatinga, 21:31-39.

Moura ON, Passos MAA, Ferreira RLC, Molica SG, Lira Junior MA, Lira MA \& Santos MVF (2006a) Distribuição de biomassa e nutrientes na parte aérea de Mimosa caesalpiniaefolia Benth. Revista Árvore, 30:877-884.

Moura ON, Passos MAA, Ferreira RLC, Molica SG, Lira MA \& Cunha MV (2006b) Conteúdo de nutrientes na parte aérea e eficiência nutricional em Mimosa caesalpiniifolia Benth. Revista Brasileira de Ciências Agrárias, 1:23-29.

Müller-Dombois D \& Ellenberg H (1974) Aims and methods for vegetation ecology. New York, John Wiley \& Sons. 547p.

Pinto SIC, Neto AEF, Neves JCL, Faquin V \& Moretti BS (2011) Eficiência nutricional de clones de eucalipto na fase de mudas cultivadas em solução nutritiva. Revista Brasileira de Ciência do Solo, 35:523-533.
Ribeiro Filho NM, Caldeira VPS, Florêncio IM, Azevedo DO \& Dantas JP (2007) Avaliação comparada dos índices químicos nitrogênio e fósforo nas porções morfológicas das espécimes de faveleira com espinhos e sem espinhos. Revista Brasileira de Produtos Agroindustriais, 9:149-160.

Sampaio EVSB \& Freitas ADS (2008) Produção de biomassa na vegetação nativa do semi-árido nordestino. In: Menezes RSC, Sampaio EVSB \& Salcedo IH (Eds.) Fertilidade do solo e produção de biomassa no semi-árido. Recife, Editora Universitária/ UFPE. p.11-26.

Sanquetta CR (2002) Métodos de determinação de biomassa florestal. In: Sanquetta CR, Watzlawick LF, Balbinot R, Ziliotto MAB \& Gomes FS (Eds.) As florestas e o carbono. Curitiba, Imprensa Universitária da UFPR. p.119-140.

Santos HG, Jacomine PKT, Anjos LHC, Oliveira VA, Lumbreras JF, Coelho MR, Almeida JA, Cunha TJF \& Oliveira JB (2013) Sistema brasileiro de classificação de solos. Rio de Janeiro, Embrapa. 353p.

Scoriza RN \& Piña-Rodrigues CM (2014) Influência da precipitação e temperatura do ar na produção de serapilheira em trecho de floresta estacional em Sorocaba, SP. Floresta, 44:687-696.

Silva AMO, Freire FJ, Barbosa MD, Ferreira RLC, Freire MBGS, Alves Junior FT, Freire CS \& Silva ACF (2018) Compartmentalization and efficiency biological of nitrogen utilization in dry tropical forest. Revista Brasileira de Ciências Agrárias, 13:e5519.

Silva FAS \& Azevedo CAV (2016) The Assistat Software Version 7.7 and its use in the analysis of experimental data. African Journal of Agricultural Research, 11:3733-3740.

Silva FC (2009) Manual de análises químicas de solos, plantas e fertilizantes. Brasília, Embrapa. 627p.

Silva GC \& Sampaio EVSB (2008) Biomassas de partes aéreas em plantas da Caatinga. Revista Árvore, 32:567-575.

Silva RKS, Feliciano ALP, Marangon LC, Freire MBGS, Freire FJ, Lima RBA, Schossler TR \& Silva ACF (2017) Soil fertility as a predictor of geospatial distribution of forest species in natural regeneration in Brazil. Journal of Experimental Agriculture International, 19:01-18.

Tedesco MJ, Volkweiss SJ \& Bohnen H (1995) Análises de solo, plantas e outros materiais. $2^{\mathrm{a}}$ ed. Porto Alegre, UFRGS. $174 \mathrm{p}$.

Teixeira PC, Donagemma GK, Fontana A \& Teixeira WG (2017) Manual de métodos de análise de solos. Rio de Janeiro, Embrapa. $573 \mathrm{p}$.

Turner BL, Brenes-Arguedas T \& Condit R (2018) Pervasive phosphorus limitation of tree species but not communities in tropical forests. Nature, 555:367-370.

Vendrami JP, Jurinitz CF, Castanho CT, Lorenzo L \& Oliveira AA (2012) Litterfall and leaf decomposition in forest fragments under different successional phases on the Atlantic Plateau of the state of Sao Paulo, Brazil. Biota Neotropica, 12:136-143.

Vitousek PM \& Sanford JR (1986) Nutrient cycling in most tropical forest. Annual Review of Ecology Systematics, 17:137-167.

Zar HJ (2010) Biostatistical analysis. $5^{\text {th }}$ ed. New Jersey, Prentice Hall. 944p.

Rev. Ceres, Viçosa, v. 66, n.5, p. 387-394, sep/oct, 2019 